\author{
담수순화 감성돔 Acanthopagrus schlegelii 동결보존 \\ 정자의 수정능력 \\ 손맹현 · 임한규· 도용현 · 정민환 ${ }^{+}$ \\ (국립수산과학원)
}

\title{
Fertilization Ability of Cryoperserved Sperms of Black Porgy Acanthopagrus schlegelii Acclimated in Freshwater
}

\author{
Maeng Hyun SON $\cdot$ Han Kyn LIM $\cdot$ Yong Hyun DO $\cdot$ Min Hwan JEONG ${ }^{+}$ \\ (National Fisheries Research and Development Institute)
}

\begin{abstract}
Fertilization rates were over 90\% when sperm from black porgy Acanthopagrus schlegelii acclimated and raised in freshwater and black porgy raised in seawater were fertilized with eggs from female black porgy raised in seawater, although cryopreserved sperm were significantly lower in fertilization rates than non-cryopreserved sperm. From the observations of embryos development at different salinities $(0,10,20$ and $32 \mathrm{psu})$ within 3 hours upon fertilization ( 16 cell stage), all were dead at 0 psu. However, the development process and speed at 10 and 20 psu were the same as at 32 psu. But, many developing embryos were egg envelope injury at low-salinities of 10 and 20 psu unlike at 32 psu. This is attributable to osmotic shock. Hatching rate of embryos at 32 psu was $60 \%$ or so, whereas low as $5 \%$ or less were successfully hatched at 10 and 20 psu, implying that osmotic shock could be responsible for the failure of embryo development.
\end{abstract}

Key words : Acanthopagrus schlegelii, Freshwater acclimation, Cryopreserved sperm, Fertilization, Salinity

$$
\text { I. 서 론 }
$$

어류의 알도 삼투압조절을 하며, 환경수와 동일 한 염분에서 원활한 삼투압조절을 하기위해 난막 의 두께나 이온농도 등이 다르다. 일반적으로 경 골어류의 알은 성어의 체액에 가까운 삼투질농도 를 유지하며, 일부 어종에서는 낭배기에 삼투압조 절과 이온 전이(Alderdice, 1998), 발생 배(embryo)
내 염류세포의 존재가 확인되었다(Guggino, 1980; Hwang \& Hirano, 1985). 이것은 수정란이 초기 발생동안 삼투압조절 능력을 가지고 있다는 것을 증명하는 것으로 볼 수 있으며, 이로 인해 환경 수의 염분은 발생 배의 생존율 및 부화율에 영향 을 주는 요인으로 작용 할 수 있다.

감성돔 Acanthopagrus schlegelii을 장기간 담수 에서 사육하였을 때, 성장과 생리활성이 정상적

\footnotetext{
† Corresponding author : 051-720-2434, mhjeong@nfrdi.go.kr

* 본 연구는 한국과학재단 목적기초연구(과제번호: R01-2004-000-10251-0)와 국립수산과학원 경상과제 (과제번호: RP-2012-AQ-009) 지원으로 수행되었습니다.
} 
이었으며, 생식 및 내분비계 호르몬의 활성과 분 비도 정상적으로 작용하였다. 또한 감성돔은 담 수에서 본연의 생식주기 및 정자형성 등 번식과 관련된 기본 특성 또한 변하지 않아 정상적으로 정자가 형성되었다(Jeong et al., 2010). 그러나 장 기간 담수에서 사육한 감성돔으로부터 채취한 정 자라 할지라도 염분이 $0 \mathrm{psu}$ 인 담수에서는 운동 성을 획득하지 못하므로 정상적인 수정이 이루어 지기 어렵다(Jeong \& Chang, 2011). 따라서 담수 에서 감성돔의 종묘생산을 위해서는 수정 및 부 화가 가능한 염분 범위를 찾는 것이 매우 중요하 다.

본 연구에서는 장기간 담수에서 사육한 감성돔 으로부터 채취한 정액을 이용하여 종묘생산시 정 자의 수정능력과 염분에 따른 수정란의 발생 및 부화율 등을 알아보기로 하였다. 이를 위하여 담 수에서 사육한 감성돔(담수감성돔)과 해수에서 사육한 감성돔(해수감성돔)의 동결정자와 해수감 성돔의 비동결정자를 이용하여 해수감성돔의 알 과 인공수정하여 수정률과 염분별 난 발생 과정 및 생존율을 비교하였다.

\section{II . 재료 및 방법}

\section{1. 실험어, 채란·채정 및 동결정자}

인공수정에 사용한 해수감성돔의 정액과 알은 국립수산과학원 종보존연구센터의 유수식 수조에 서 사육중이던 친어(전장 $35.4 \pm 4.9 \mathrm{~cm}$, 체중 1,180 $\pm 135.0 \mathrm{~g}$ )로부터 채취하였다. 현장에서 실험어를 200 ppm 2-phenoxyethanol로 마취한 다음 복부를 부 드럽게 압박하여 채란 · 채정하였다.

실험에 사용한 동결정자는 담수 및 해수순환여 과수조에서 1 년 이상 장기간 실내 사육한 2년생 감성돔(담수감성돔: 전장 $22.5 \pm 1.8 \mathrm{~cm}$, 체중 $232.4 \pm 55.6 \mathrm{~g}$, 해수감성돔: 전장 $21.7 \pm 1.9 \mathrm{~cm}$, 체중 $185.0 \pm 47.3 \mathrm{~g}$ )으로부터 채취하였다. 인공수정에 사 용한 동결정자는 이전 연구에서 생존율과 정자활 성지수(sperm activity index, SAI)가 가장 높았던 $10 \%$ dimethyl sulfoxide (DMSO)를 이용하여 동 결한 보존 1 년째의 담수감성돔 동결정자 (cryopreserved sperm of black porgy reared in freshwater, $\mathrm{CSF}$ )와 해수감성돔 동결정자 (cryopreserved sperm of black porgy reared in seawater, CSS)를 사용하였다. 동결정자는 인공수 정 직전에 $25^{\circ} \mathrm{C}$ 의 항온수조에 30 초간 급속 해동 후 바로 알과 수정시켰다.

\section{2. 인공수정 및 난발생}

해동한 $\mathrm{CSF}$ 및 $\mathrm{CSS}$ 의 생존율과 $\mathrm{SAI}$ 는 각각 $60 \%, 2.0$ 이상이었으며, 대조구로 사용한 해수감 성돔 정자(fresh sperm of black porgy reared in seawater, FSS)는 채정 후, 인공수정 전까지 얼음 을 채운 ice box에 보관하였다. 해수감성돔 암컷 으로부터 채란한 알은 여과해수가 담긴 비커에 넣어 부상한 알만을 인공수정에 사용하였다. 인 공수정은 건식법으로 했으며, 알과 각각의 정액 별로 잘 섞은 후, 여과해수를 사용하여 3 회 세란 하였다. 이후 수정여부를 판별하기 위하여 수정 1 시간 30 분 후 2 세포기 이상으로 발생이 진행된 배만을 수정된 것으로 판정하였다.

정액별로 인공수정시킨 각각의 수정란을 수온 $20^{\circ} \mathrm{C}$, 염분 $0,10,20$ 및 $32 \mathrm{psu}$ 의 부화용수가 담 긴 $500 \mathrm{~mL}$ 비커에 각각 $500 \pm 20$ 개씩 넣어 염분별 수정란의 부상률을 확인하였다. 이 후 4 세포기 부터 포배기까지는 30 분 간격으로, 포배기부터 부화까지는 1 시간 간격으로 광학현미경을 이용하 여 발생과정, 부화시간 및 생존율을 측정하였다. 발생 배의 생존율은 백탁된 알은 죽은 것으로 간 주하고, 전체 알에서 죽은 알을 제외한 백분율로 나타내었다.

\section{3. 통계처리}

모든 측정값은 평균표준편차로 나타냈으며, 유의차는 SPSS-통계패키지(version 12.0)를 이용 
하여 one-way ANOVA-test로 검정하였으며, 집 단간의 다중비교는 Duncan's multiple range test 에 의해 검정하였다.

\section{III. 결 과}

\section{1. 수정률}

$\mathrm{CSF}$ 와 CSS를 이용하여 해수감성돔 알과 수정 시킨 알의 수정률은 [Fig. 1]에 나타내었다. 각각 의 정액별로 수정시킨 알은 대부분 수정 1시간 30 분 후에 2 세포기에 도달하였다. CSF와 CSS의 수정률은 각각 $93.0 \pm 2.0,93.0 \pm 1.7 \%$ 로 유의한 차 이를 보이지 않았으나, FSS의 수정률은 $96.0 \pm 1.7 \%$ 로 동결정자인 CSF 및 CSS 보다 유의하게 높았 다 $(\mathrm{P}<0.05)$. 각각의 정액별로 수정한 2 세포기의 수정란을 염분 $0,10,20$ 및 $32 \mathrm{psu}$ 부화용수에 각각 넣었을 때, $32 \mathrm{psu}$ 에서는 $100 \%$ 부상했으나, 담수 또는 저염분해수인 0,10 및 $20 \mathrm{psu}$ 에서는 모두 바닥으로 가라앉았다.

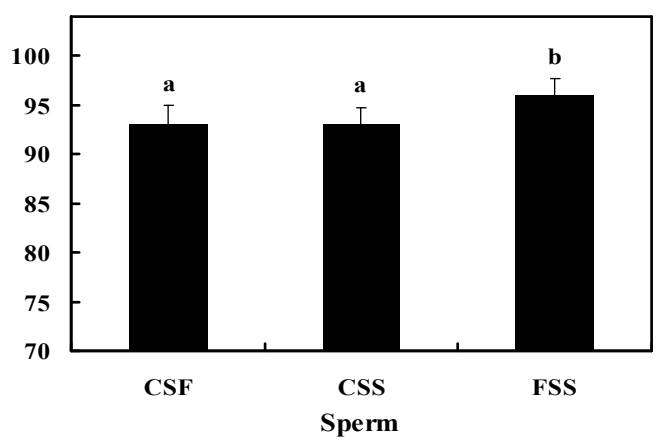

[Fig. 1] Fertilization rate of cryopreserved and fresh sperm of black porgy Acanthopagrus schlegelii reared in freshwater and seawater $(P<0.05)$. CSF: cryopreserved sperm of BFW, CSS: cryopreserved sperm of BSW, FSS: fresh sperm of BSW

\section{2. 난발생}

$\mathrm{CSF}, \mathrm{CSS}$ 및 FSS를 이용하여 해수감성돔 알과 수정시킨 수정란을 $0,10,20$ 및 $32 \mathrm{psu}$ 부화용수 에 각각 넣어 발생과정을 관찰한 결과는 [Fig. 2] 와 같다. 수온 $20^{\circ} \mathrm{C}$, 염분 $0 \mathrm{psu}$ 의 부화용수(담 수)에 넣은 각각의 정액별 수정란(2 세포기)은 4 세포기까지 대부분 생존하였으나, 이후 급격하게 생존율이 감소하여 대부분 16 세포기 이전에 폐 사하였다. 다른 염분농도의 부화용수에서는 정액 별, 염분별로 수정란은 정상발생 하였으며, 각각 의 발생단계에 이르는 시간 역시 차이를 보이지 않았다. 수정 1 시간 후에 $70 \%$ 이상의 알이 수정 막을 형성하였으며, 수정 2시간에 4 세포기, 3시 간에는 16 세포기에 도달하였다. 이후 분열은 계 속되어 수정 4 시간 30 분에 상실기, 수정 8 시간에 포배기, 13 시간에 낭배기까지 발생하였다. 이후 배체가 출현하기 시작하여 수정 21시간 후에 안 포형성기에 도달하고, Kupffer씨포가 형성되었으 며, 36시간 후에 심장박동이 일어났다. 수정 37시 간에는 꼬리가 형성되면서 Kupffer씨포가 소실되 고, 38시간에 꼬리에 지느러미가 형성되었다. 수 정 39시간 후부터 난막을 뚫고 부화하는 개체가 관찰되기 시작하였으며, 수정 43 시간 후에는 대 부분 부화하였다.

\section{3. 생존율}

정액별, 염분별 4 세포기부터 발생 배의 주요 단계별 생존율을 관찰한 결과는 [Fig. 3]과 같다. FSS로 인공수정한 발생 배는 4 세포기 때 염분 $0,10,20$ 및 $32 \mathrm{psu}$ 에서 모두 $100 \pm 0.0 \%$ 생존하 였으나, 64 세포기로 발달하였을 때는 생존율이 각각 $0.0 \pm 0.0,93 \pm 3.1,98 \pm 1.0$ 및 $100 \pm 0.0 \%$ 로 저염 분해수에서는 생존율이 감소하였다. 염분 10,20 $\mathrm{psu}$ 의 저염분해수에서 발생 배의 생존율은 포배 기 이후 급격하게 감소하여 낭배기 때 생존율은 $32 \mathrm{psu}$ 에서는 $84 \pm 3.5 \%, 10,20 \mathrm{psu}$ 에서는 각각 $59 \pm 7.9,57 \pm 8.5 \%$ 로 감소했다. Kupffer씨포 단계에 이르러서는 $32 \mathrm{psu}$ 에서 생존율은 $70 \pm 7.5 \%$ 인데 


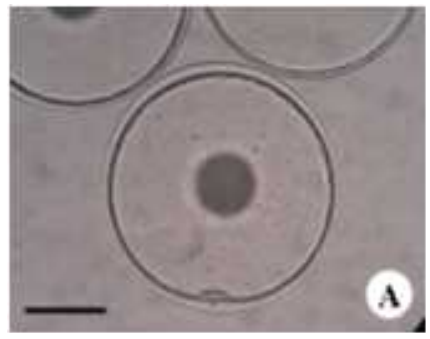

Fertilized egg

$1 \mathrm{~h}$

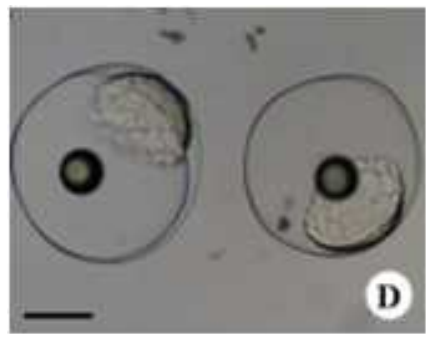

Morula stage

$4.5 \mathrm{~h}$

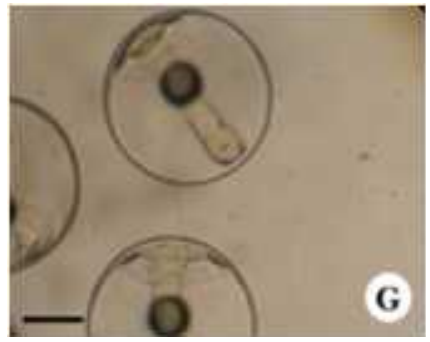

Formation of optics vesicles $21 \mathrm{~h}$

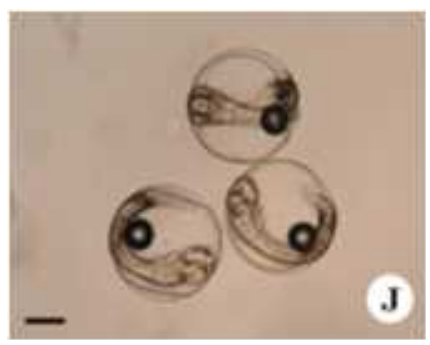

Formation of tail fin $38 \mathrm{~h}$

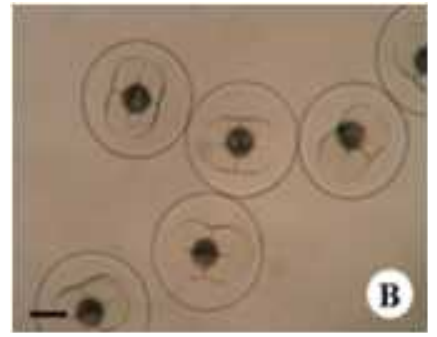

4 -cell stage

$2 \mathrm{~h}$

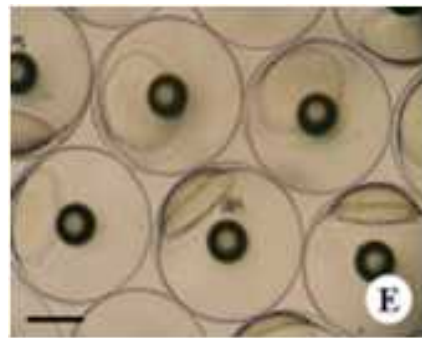

Blastula stage

$8 \mathrm{~h}$

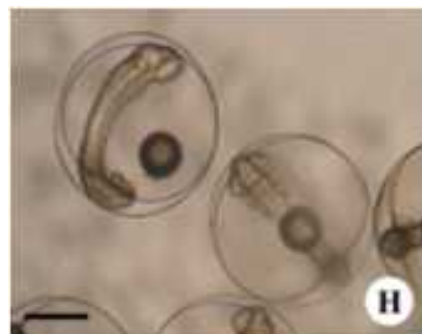

Formation of heart and tail $36 \mathrm{~h}$

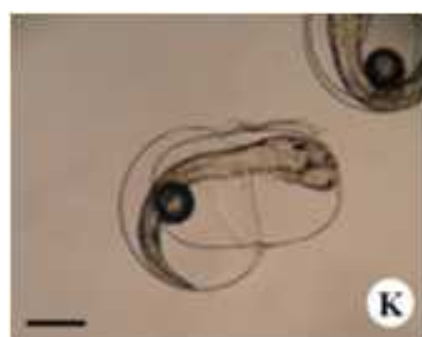

Just before hatching $39 \mathrm{~h}$

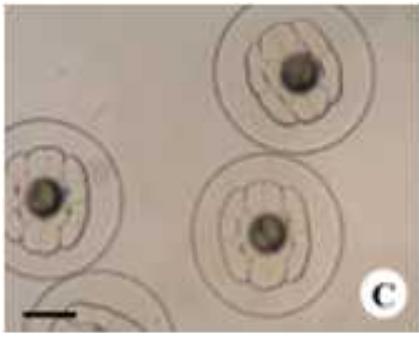

16-cell stage $3 \mathrm{~h}$

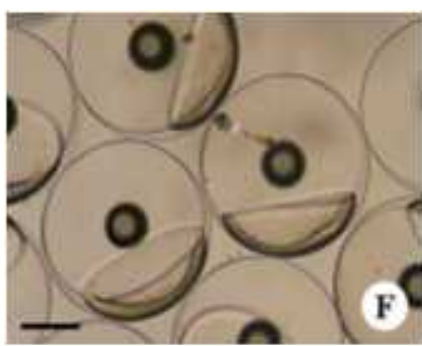

Gastrula stage

$13 \mathrm{~h}$

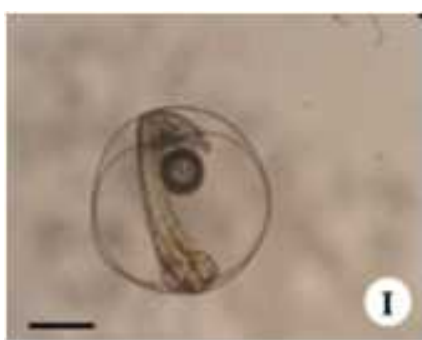

Disappearance of Kupffer's vesicle $37 \mathrm{~h}$

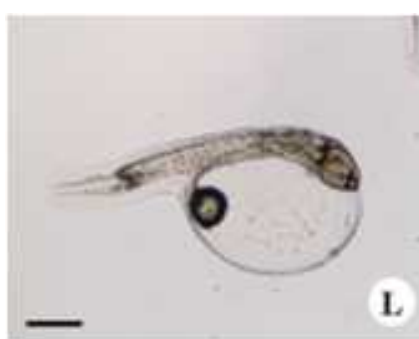

Hatched larva

$43 \mathrm{~h}$

[Fig. 2] Egg development on cryopreserved sperm of black porgy Acanthopagrus schlegelii reared in freshwater and seawater. Bars $=300 \mu \mathrm{m}$ 
반해 $10,20 \mathrm{psu}$ 에서는 각각 $19 \pm 5.5,16 \pm 9.5 \%$ 로 생존율이 $20 \%$ 미만으로 감소하였다. 최종적으로 $32 \mathrm{psu}$ 에서 발생 배의 부화가 $90 \%$ 이상 되었을 때 생존율은 $60 \pm 5.7 \%$ 였으나, $10,20 \mathrm{psu}$ 에서는 각각 $2 \pm 1.5,3 \pm 2.6 \%$ 로 모두 $3 \%$ 이하의 매우 낮 은 생존율을 보였다. CSF로 인공수정한 발생 배 의 경우, 4 세포기 때 $0,10,20$ 및 $32 \mathrm{psu}$ 의 부 화용수에서 생존율이 각각 $97 \pm 1.5,98 \pm 1.0,98 \pm 0.6$ 및 $100 \pm 0.0 \%$ 이었으며, 포배기 단계에서는 각각 $0 \pm 0.0,85 \pm 5.3,85 \pm 1.5$ 및 $95 \pm 1.7 \%$ 로 $32 \mathrm{psu}$ 에서 는 높게 유지된 반면, $10,20 \mathrm{psu}$ 에서는 감소하였 다. 저염분해수에서 발생 배의 생존율 감소는 포 배기 이후 급격하게 감소하여 낭배기 단계에서 생존율이 $32 \mathrm{psu}$ 에서는 $80 \pm 4.9 \%, 10,20 \mathrm{psu}$ 에서 는 각각 $55 \pm 7.0,57 \pm 6.1 \%$ 로 감소하였다. Kupffer 씨포 단계에 이르러서는 $32 \mathrm{psu}$ 에서는 $69 \pm 3.1 \%$, $10,20 \mathrm{psu}$ 에서는 각각 $20 \pm 7.8,40 \pm 9.0 \%$ 로 감소하 였다. 최종적으로 $32 \mathrm{psu}$ 에서 발생 배의 부화율 이 $90 \%$ 에 이르렀을 때 생존율은 $60 \pm 6.2 \%$ 였으나, $10,20 \mathrm{psu}$ 에서는 각각 $3 \pm 1.0,2 \pm 0.0 \%$ 로 매우 낮 았다. CSS의 염분별 발생 배의 생존율 역시 CSF 와 비슷한 경향을 보였다.

\section{4. 수정란 및 부화자어의 형태적 손상}

부화용수의 염분별 발생과정 중 일반해수인 32 $\mathrm{psu}$ 에서는 수정란이 정상적으로 발생한 반면, 저 염분해수 $(10,20 \mathrm{psu})$ 에서는 발생 배 및 부화자어 의 난막 및 난황에 형태적 손상이 관찰되었다 [Fig. 4]. 저염분해수에서 가장 많이 관찰되었던 난막 손상은 정상적인 난막이 관찰되는 [Fig. 4-A]와 달리 [Fig. 4-B]에서 보는 바와 같이 난막 의 일그러짐(잔주름)이 많았다. 특히 심한 것은 난막의 한쪽이 터져 난황이 외부로 유출되는 발 생 배도 일부 관찰되었다[Fig. 4-D].

저염분해수에서 관찰된 발생 배의 난막 손상은 부화자어에서도 관찰되었다. [Fig. 4-E]에서 보는 바와 같이 갓 부화한 자어의 난황은 투명하고 매
끄러운 데 반해, 저염분해수에서 갓 부화한 자어 의 난황은 [Fig. 4-F]처럼 난황 표면에 홈이 생기 거나, 오돌토돌한 작은 돌기들이 관찰되었다. 또 한 이러한 형태적 손상을 보인 발생 배 및 부화 자어는 발생도중 폐사하거나, 부화하더라도 곧 폐사하였다.
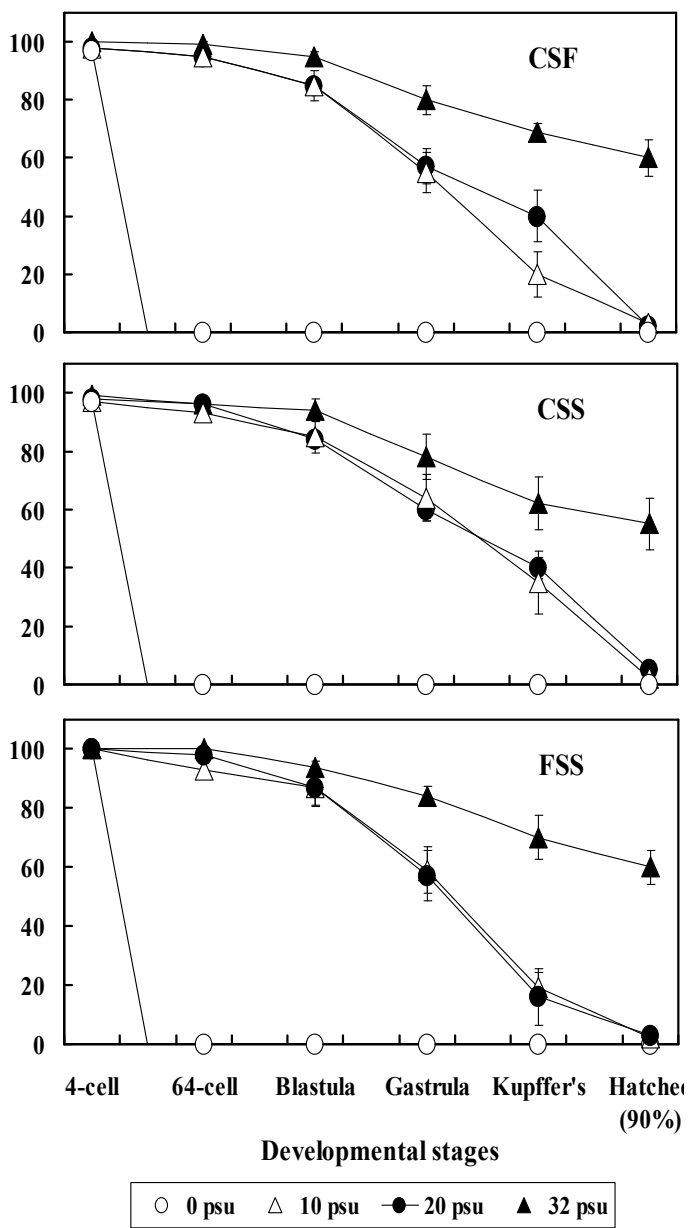

[Fig. 3] Survival rate of black porgy Acanthopagrus schlegelii embryos with each sperm and salinity. CSF: cryopreserved sperm of black porgy reared in freshwater, CSS: cryopreserved sperm of black porgy reared in seawater, FSS: fresh sperm of black porgy reared in seawater 


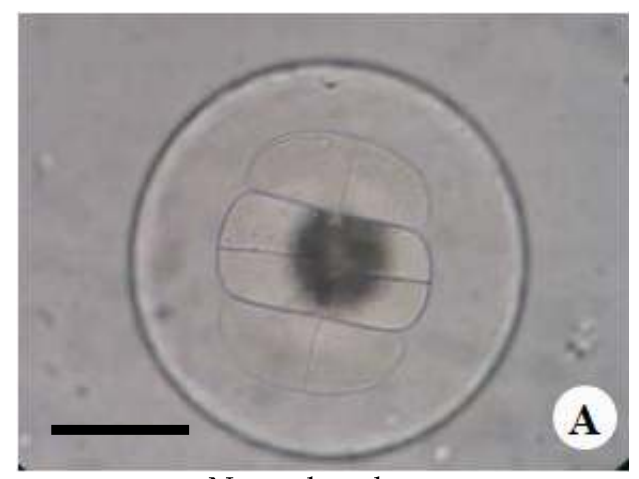

Normal embryo

(32 psu, 8-cell stage)

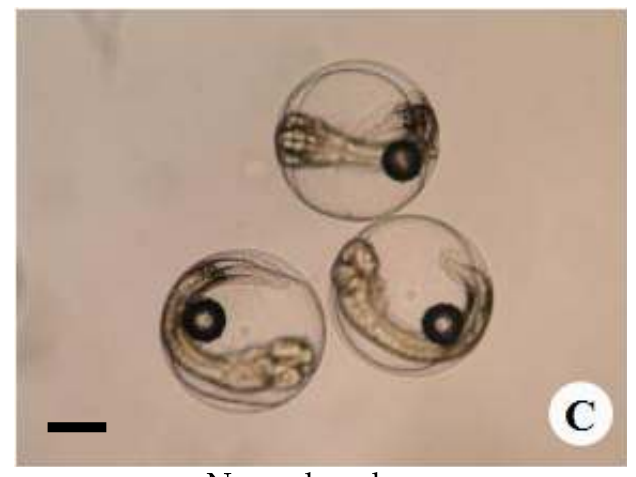

Normal embryo

(32 psu, formation of caudal fin)

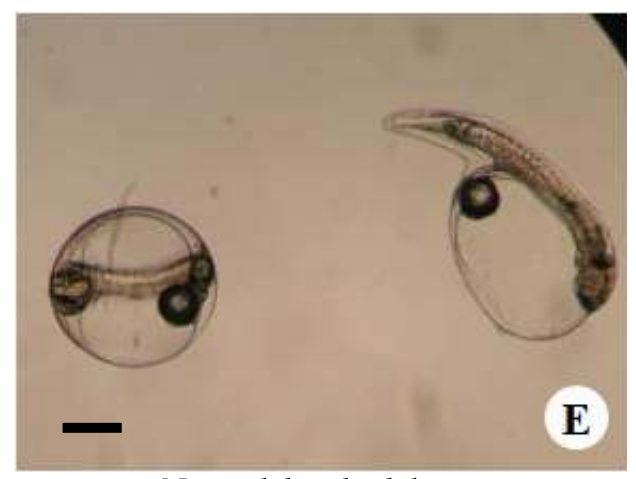

Normal hatched larva

(32 psu)

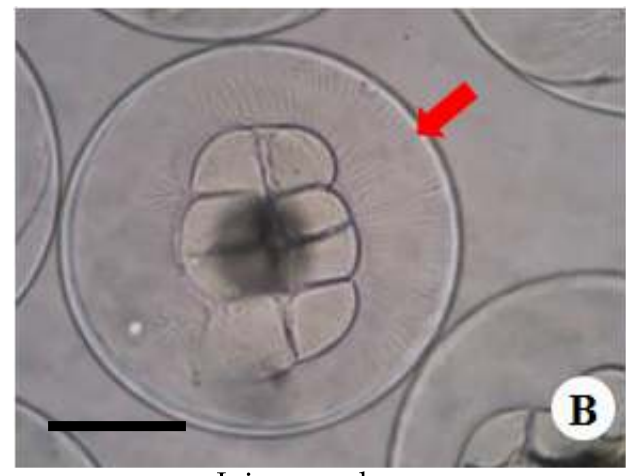

Injury embryo

(10 psu, 8-cell stage)

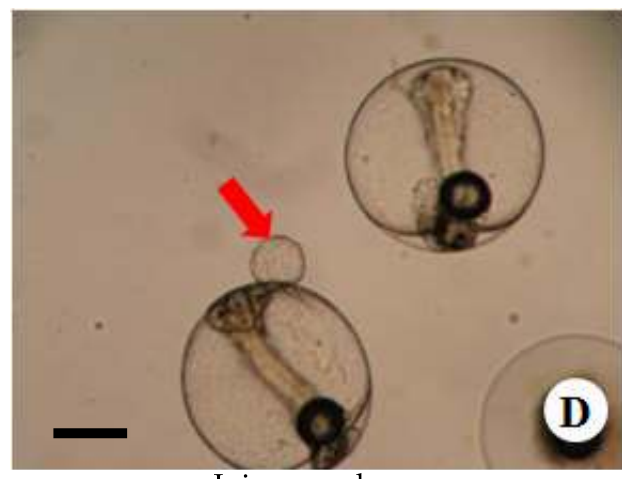

Injury embryo

(20 psu, formation of caudal fin)

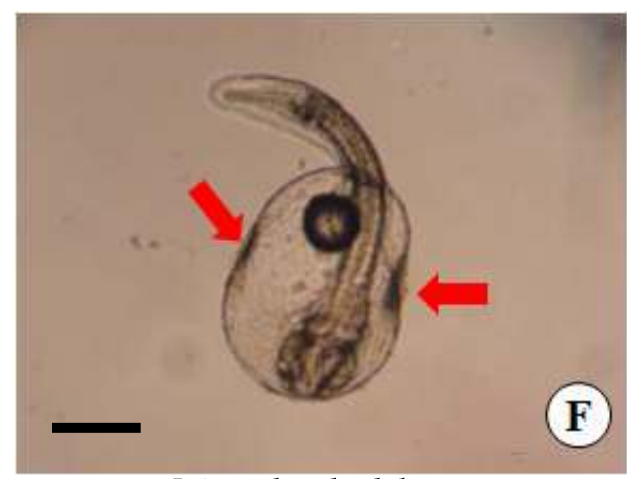

Injury hatched larva

(20 psu)

[Fig. 4] Injury to egg envelope embryos and yolk hatched larvae of black porgy Acanthopagrus schlegelii from the eggs incubate with low salinity seawater of 10 and 20 psu. Arrows indicate morphologically injury positions. Bars $=300 \mu \mathrm{m}$

\section{IV. 고 찰}

일반적으로 어류의 종묘생산 과정에서 수온과
염분은 수정란의 대사, 난 발생 및 자·치어의 성장과 생존에 영향을 미치는 중요한 요인이며 (Hokanson et al., 1973; Gunnes, 1979; Walsh et 
al., 1991; Lee et al., 1992), 이로 인해 부화시간 및 부화율에도 영향을 미치는 것으로 알려져 있 다(Young \& Dueňas, 1993). Holliday (1969)는 환경요인 중 염분이 종묘생산 과정 중에 자어의 성장과 생존율뿐만 아니라 부화율, 자어의 활력, 난황흡수, 먹이효율 등에 영향을 미치고, 특히 산 란, 발생, 부화하는 데 염분에 의해 큰 영향을 받 는다고 하였다. 독가시치를 대상으로 염분범위 0 73 psu에서 부화시간은 염분과 역상관계를 보 였으며, 부화율은 최저와 최고의 염분에서 감소 하였다(Young \& Dueňas, 1993). Lee et al. (1997) 의 참가자미 Limanda herzensteini를 이용한 연구 에서 정상 염분인 $35 \mathrm{psu}$ 와 고염분인 $38 \mathrm{psu}$ 에 서 수정란은 정상적으로 발생 및 부화가 이루어 졌으나, 저염분 해수인 $27 \mathrm{psu}$ 이하에서는 전량 폐사하였다고 하였다. 그러나 염분에 따른 난 발 생 속도에는 차이가 없어 염분과 난 발생은 관계 가 없는 것으로 보고하였다. 본 연구에서 $10 \%$ $\mathrm{DMSO}$ 로 동결하여 1년간 보존한 담수 및 해수감 성돔 동결정액을 이용하여 해수감성돔 알과 인공 수정시킨 결과, 해수감성돔 알과 정액으로 인공 수정시킨 것보다 낮았지만 모두 $90 \%$ 이상의 높은 수정률을 보였다. 따라서 장기간 담수에서 사육 한 감성돔으로부터 채취한 정액을 이용하여 종묘 생산을 하는 데는 생물학적으로 어려움이 없는 것으로 판단된다. 또한 이렇게 인공수정하여 얻 은 수정란(2 세포기)을 $0,10,20$ 및 $32 \mathrm{psu}$ 부화 용수에 넣어 염분별 난 발생 과정을 관찰한 결 과, $0 \mathrm{psu}$ 에서는 수정 후 3 시간 내에(16 세포기) 모두 폐사하였지만, $10,20 \mathrm{psu}$ 는 자연해수인 32 $\mathrm{psu}$ 와 동일한 발생과정 및 발생속도를 보였다. 한편 저염분해수인 $10,20 \mathrm{psu}$ 에서는 $32 \mathrm{psu}$ 에서 관찰되지 않던 난막 손상이 관찰되었다.

Go \& Rho (1996)의 자주복 Takifugu rubripes 을 이용한 수정란 및 자-치어의 저염분 내성 연 구에서 자주복은 $0 \mathrm{psu}$ 에서 부화되지 않지만, 3.5 $\mathrm{psu}$ 에서 $24.7 \%$ 의 부화율을 보였다고 보고하였다. 그러나 저염분일수록 기형률이 $27.0 ~ 47.0 \%$ 로 증
가하였을 뿐만 아니라 부화 이후 폐사율이 높게 나타났다고 하였다. 또한 Hwang et al. (2008)의 고등어 Scomber japonicus를 이용한 연구에서 자 연산란 염분 범위인 33 35 psu에서 높은 부화율 을 보였으며, 염분이 낮을수록 부화율이 낮은데 다 기형어 발생률은 저염분인 $10 \mathrm{psu}$ 와 고염분인 $37 \mathrm{psu}$ 에서 높게 나타났다고 하였다. 이상의 연 구에서 저염분해수에 의한 수정란 및 부화자어의 기형에 대한 자세한 묘사는 없었으나, 본 연구에 서 관찰된 수정란 난막의 일그러짐, 난황의 난막 외부로 유출 그리고 부화자어의 난황형태 기형 등일 것으로 추정된다. 이러한 기형은 삼투압충 격에 의해 발생한 것으로 판단되며, 수정란 난막 의 일그러짐 현상은 외부의 저삼투질농도의 부화 용수가 난막 안으로 침투하여 난막이 팽창하였다 가 수정란의 삼투질농도가 부화용수의 삼투질농 도와 평형을 이룬 후, 팽창된 난막이 줄어들면서 생긴 흔적으로 추정된다. 또한 수정란 난황의 난 막 외부 돌출은 부화용수가 난막 안으로 침투하 면서 난막이 이를 견디지 못한 결과라고 판단된 다. 이렇게 난 발생 과정에서 일어나는 삼투압충 격은 갓 부화한 자어에까지 이어져 부화자어의 기형에 영향을 미칠 것으로 추정된다.

Young \& Dueňas (1993)의 독가시치를 이용한 연구에서는 $4 \mathrm{psu}$ 의 저염분해수에서 $50 \%$ 이상의 부화율을 나타내었지만, 불완전한 부화(partial hatching)와, 부화 후 낮은 생존율 및 부화자어의 높은 기형률을 보고하였다. 특히 이러한 불완전 한 부화는 저비중에 의한 배체 발달, 운동성 저 하, 미부 근조직의 비정상 발생 등에 의해 부화 전 배체가 난막을 뜷고 나오는 것을 어렵게 만든 다고 하였다(Holliday, 1965, 1969). 본 연구에서 자연해수인 $32 \mathrm{psu}$ 에서 정액조건별 수정란의 생 존율은 모두 $60 \%$ 전후였으나, 다른 저염분해수 $(10,20 \mathrm{psu})$ 에서는 5\% 미만의 매우 낮은 생존율 을 보였다. 수정란을 저염분해수에 수용하여 발 생과정을 관찰하던 중 발생 배의 난막 손상이나 부화자어의 난황 이상 등 형태적 손상이 관찰되 
었다. 이러한 형태적 손상은 삼투압충격에 의해 발생한 것으로 판단되며, 이는 직간접적으로 수 정란의 생존율을 감소시켰을 것이다. 또한 저염 분해수에서 수정란은 모두 바닥에 가라앉아 발생 하였으며, 바닥에 살아있는 알 주변에는 죽은 알 들이 존재하였다. 수정란의 발생기간 동안 죽은 알들을 지속적으로 제거하였지만, 이로 인해 발 생한 수생균이나 곰팡이 등은 살아있는 발생 배 를 오염시켰을 것이며 생존율 감소에 적지 않은 영향을 미쳤을 것으로 판단된다.

\section{참고 문헌}

Alderdice, D.F.(1998). Osmotic and ionic regulation in teleost eggs and larvae. 99, 163 251. (in) Fish Physiology (eds) Hoar WS and Randall DJ. Vol. 11, Part A, Academic Press, New York.

Go, H.B. \& Rho, S.(1996). Low salinity tolerance of eggs and juveniles of tiger puffer, Takifugu rubripes, Journal of Aquaculture 9, 43 55.

Guggino, W.B.(1980). Salt balance in embryos of Fundulus heteroclitus \& $F$. bermudae adapted to seawater, American Journal of Physiology 238, 42 49.

Gunnes, K.(1979). Survival and development of Atlantic salmon eggs and fry at three different temperatures, Aquaculture 16, 211 218.

Hokanson, K.E.F., McCormick. J.M. \& Jones, B.R.(1973). Temperature requirements for embryos and larvae of the northen pike, Esox lucius (Linnaeus), Transactions of the American Fisheries Society 102, 89 100.

Holliday, F.G.T.(1965). Osmoregulation in marine teleost eggs and larvae, California Cooperative Oceanic Fisheries Investigations Reports 10, 89 $\sim 95$.

Holliday, F.G.T.(1969). The effects of salinity on the eggs and larvae of teleost, 312 318, (in) Fish Physiology Vol. 1 (eds,) Hoar WS and
Randall DJ, Academic Press, New York. Hwang, H.K., Kim, D.H., Park, M.W., Yoon, S.J. \& Lee, Y.H.(2008). Effects of water temperature and salinity on the egg and larval of chub mackerel Scomber japanicus, Journal of Aquaculture 21, 234 238.

Hwang, P.P. \& Hirano, R.(1985). Effects of environmental salinity on intercellular organization and junctional stucture of chloride cells in early stages of teleost development, Journal of Experimental Zoology 236, 115 126.

Jeong, M.H., Lim, H.K., Kim, Y.S., Kim, S.Y. \& Chang, Y.J.(2010). Sperm collection time, sex steroid hormones and gonadal development of black porgy, Acanthopagrus schlegeli acclimated in freshwater, Korean Journal of Fisheries Aquatic Science 43, 474 481.

Jeong, M.H. \& Chang, Y.J.(2011). Properties of Semen and Sperm Motility of Black Porgy Acanthopagrus schlegelii Acclimated in Freshwater, Development \& Reproduction 15, 151 158.

Lee, C.S., Tamaru, C.S., Kelley, C.D., Moriwake, A. \& Miyamoto, G.T.(1992). The effect of salinity on the induction of spawning and fertilization in the striped mullet, Mugil cephalus, Aquaculture 101, 289 296.

Lee, J.Y., Kim, W.K. \& Chang, Y.J.(1997). Influence of water temperature and salinity in egg development of flatfish, Limanda herzensteini, Journal of Aquaculture 10, 357 362.

Walsh, W.A., Swanson, C. \& Lee, C.S.(1991). Combined effects of temperature and salinity on development and hatching of striped mullet, Mugil cephalus. Aquaculture 97, 281 289.

Young, P.S. \& Dueňas, C.E.(1993). Salinity tolerance of fertilized egg and yolk-sac larvae of the rabbitfish, Siganus guttatus (Bloch). Aquaculture 112, 363 377.

- 논문접수일 : 2012년 03월 27일

- 심사완료일 : 1차 - 2012년 05월 30일

- 게재확정일 : 2012년 06월 03일 